\title{
SOBRE O CAMPO DA PSICOLOGIA SOCIAL'
}

\author{
Belinda Mandelbaum
}

Resumo: O campo da Psicologia Social é apresentado como território fértil, na contemporaneidade, para constituir-se como um laboratório para a produção em Ciências Humanas, uma vez que, no século XX, cada vez mais o social foi em direção ao psicológico. Neste campo, nosso embate dá-se no modo como entendemos o hífen pressuposto na integração psicossocial. A autora propõe que, entre o psicológico e o social, o hífen domina, pois ele é a própria essência relacional que é inerente a cada um dos elementos. Sugere que o modelo para entender o homem e suas circunstâncias proposto por Freud imbrica de forma indissociável o psicológico e o social, a ontogênese e a filogênese, com uma potência que teve impacto sobre todo o campo das Ciências Humanas. A Psicanálise é um instrumento hermenêutico para colaborar na elucidação dos fenômenos sociais. A autora utiliza imagens construídas por Freud e Walter Benjamin e poemas de Carlos Drummond de Andrade para fortalecer o entendimento do hífen psicossocial tanto em sua ação multidimensional quanto em sua organização.

Palavras-chave: Psicologia Social.Psicanálise. Memória. Reparação.

1 Este texto foi escrito como introdução à minha tese de livre-docência em Psicologia Social, intitulada Trabalhos com Famílias em Psicologia Sociale defendida no Instituto de Psicologia da USP em dezembro de 2010. 
O campo da Psicologia Social constitui-se, na atualidade, num instigante território problematizador dos modelos e métodos das Ciências Humanas. Não propomos que um ou outro método, um ou outro modelo, poderá mostrar-se, a partir desta problematização, mais eficaz na configuração desse campo. Não se trata de irmos em direção a um modelo ou método mais privilegiado. O que queremos salientar é que, na contemporaneidade, o encontro do psicológico e do social é um território fértil para constituir-se em algo assim como um laboratório para a produção em Ciências Humanas. Talvez não pequemos por exagero se dissermos que, no século XX, cada vez mais o social foi em direção ao psicológico.

Benjamin (1940/1971), em suas Teses da Filosofia da História, abre esse poderoso texto construindo uma enigmática imagem a respeito de uma imbatível máquina para ganhar no jogo de xadrez:

Como é sabido, diz-se que existia um autômato construído de tal forma que era capaz de responder a cada movimento de um jogador de xadrez com outro movimento que lhe assegurava o trunfo na partida. Um boneco vestido de turco, com a piteira de narguilé na boca, estava sentado diante do tabuleiro pousado sobre uma ampla mesa. Um sistema de espelhos produzia a ilusão de que esta mesa era em todos os sentidos transparente. Na realidade, encontrava-se lá dentro um anão corcunda, que era mestre no xadrez e mexia a mão do boneco mediante fios. Um equivalente de tal mecanismo pode imaginarse na Filosofia. Deve vencer sempre o boneco chamado “Materialismo Histórico". Pode competir sem mais com qualquer um, quando coloca a seu serviço a Teologia, que hoje, como é notório, é pequena e desagradável e não deve deixar-se ver por ninguém. (p. 77, tradução nossa)

A estranha imagem construída por Benjamin no início dos anos 40 do século passado parece servir para mapear o estado de coisas no embate teórico-filosófico no campo da Filosofia da História, nessa época. Nesta imagem, o Materialismo Histórico é capaz de ganhar os torneios teóricos graças à intervenção tanto de um complexo mecanismo especular - produtor de uma ilusão -, quanto do auxílio de um habilidoso e deformado parceiro de jogo. Através da máquina especular, o que o boneco vestido à turca aspira pela piteira de narguilé são as velhas especulações teológicas, potencializando-se o impacto das suas jogadas para vencer o jogo. A potência do Materialismo Histórico no torneio intelectual Ihe seria emprestada pela Teologia, ainda que o Materialismo, na inquietante imagem mostrada por Benjamin, seja o condutor das jogadas.

De passagem, digamos que talvez o que Benjamin não levou em consideração é que esse anão corcunda pode ser bem mais astucioso, maquinando não apenas a jogada do parceiro materialista histórico, mas, também, quem sabe, a de seu eventual adversário. Essa tese nos parece 
legítima de ser levada em consideração no contexto em que Benjamin escreveu o seu texto. Porque o adversário, na época, era o nacional socialismo alemão. $E$, talvez, o sucesso deste como fenômeno de massas tenha advindo também de alguns movimentos ilusórios deslocados desde o campo teológico, ou seja, a mesma máquina e o mesmo anão corcunda a Teologia - que amplia a potência do jogador materialista histórico teria ampliado também a potência do adversário que, no caso, diga-se também de passagem, ganhou a partida e transformou a História, nesse momento, no desastre nazista.

Mas não é propriamente este o assunto que nos fez trazer à cena a imagem com que Benjamin abre suas Teses da Filosofia da História, e que por si só constitui-se numa tese. A asserção de Benjamin implica uma estranha composição de modelos na qual o Materialismo Histórico pode servir de "boneco", por assim dizer, da ventríloqua Teologia, isto é, da concepção em princípio mais antagônica a si próprio. E é bom lembrarmos que esta imagem não é construída por qualquer pensador, mas por um polêmico do idealismo irracional da Filosofia, mas também dos aspectos reducionistas e mecanicistas do Materialismo Histórico. Mas é que Benjamin, como bem mostra nessas teses, pensa sempre na História quando pensa os modelos teóricos. E sabe, tal como ele desenvolve nas teses que se seguem a esta, que as ruínas do passado - e delas fazem parte as concepções todas sobre o homem que foram elaboradas - nunca silenciam propriamente, podendo vir a ressurgir em voz transfigurada, como a Teologia através do Materialismo Histórico, em que as expectativas revolucionárias deste são alimentadas pela velha potência histórica das expectativas redentoras da Teologia. Talvez o elemento central da imagem criada por Benjamin não seja nem o boneco vestido à turca, nem o anão corcunda, mas o sistema de espelhos produtor da ilusão de uma mesa "em todos os sentidos transparente",que vincula tempos do pensamento distanciados entre si.

No campo da Psicologia Social, nosso embate dá-se essencialmente no modo como entendemos o hífen pressuposto na integração entre o psicológico e o social, ao qual este campo de estudos parece sempre fazer referência.É a natureza deste hífen que parece sempre estar no horizonte dos estudos da Psicologia Social. Costumamos alocar este hífen numa virtual linha horizontal que separa indivíduo de coletivo e, em ressonância ideacional, o psicológico do social. Assim, o psicológico estaria em ressonância com o individual e o social em ressonância com o coletivo, e o hífen entre ambos. Claro que já aprendemos que o indivíduo é uma construção do coletivo e, portanto, que o psicológico é um produto do social. Mas também aprendemos que o indivíduo anseia pelo coletivo, o valoriza e se apega a ele com a mesma intensidade e a partir da mesma raiz a partir da qual se desdobra em sujeito. Nesse sentido, o social seria um desdobramento da demanda psicológica humana. Ou seja, 
aprendemos que, entre o psicológico e o social, o hífen domina. Um produz o outro, ao modo como, na fita de Moebius, verso e reverso realizamse transitoriamente, num contínuo infinito. Não apenas o hífen serve para indicar a existência de um conectivo entre o elemento psicológico e o elemento social, mas aqui o hífen serve para deixar surgir a própria essência relacional que é inerente a cada um dos elementos, para que estes possam existir como tais. O hífen é a natureza do psicológico e do social. Foi a história das realizações no campo das Ciências Humanas, e até das ciências em geral, que levaram a esse estado de coisas no qual o hífen se instaura para juntar campos aparentemente separados - o psicológico e o social. Não é o caso agora de mostrar como os principais modelos de compreensão do homem e suas produções operaram no intuito de sinalizar o fortalecimento da essência relacional que define o psicológico e o social. Mas, sem dúvida, precisamos pôr em destaque as contribuições de Freud. Porque, mesmo que não sejam propriamente as suas construções teóricas que tiveram um impacto mais acentuado para salientar a importância do hífen - ainda que não possamos esquecer, por exemplo, a célebre frase com que em 1921 ele abre o texto "Psicologia de grupo e a análise do ego", de que não há Psicologia que não seja Psicologia Social -, foi sem dúvida seu modelo mais geral de entender o homem que teve um impacto enorme sobre toda a produção de conhecimento no século $X X$, às vezes de forma invisível, como o anão na partida de Benjamin. Freud, ao criar e mobilizar o que poderíamos denominar de metáfora psicanalítica, isto é, o modo extremamente poderoso e singular de ao mesmo tempo estudar e dinamizar os fenômenos psicológicos, soube suscitar uma abordagem que, por suas implicações na história das Ciências Humanas, a torna, a nosso ver, um legítimo representante a ser entendido, no campo da Psicologia Social, em analogia ao anão corcunda da Teologia na imagem de Benjamin. A Psicanálise pode ser quem mobiliza os fios para os lances do jogo no interior deste campo. Claro que a Psicanálise não é a sucedânea da Teologia, se bem que, por sua potência articuladora, resquícios poderosos da Teologia possam neste discurso também ser atualizados. Mas o que queremos salientar é a ação da linguagem psicanalítica no interior do campo da Psicologia Social. Freud soube dar ao psicológico um estatuto completamente original, permitindo a nomeação de relações e encadeamentos que ampliam nossa compreensão sobre o modo como os homens se constroem. Um exemplo que pode nos servir para ilustrar o que estamos sugerindo sobre o profundo impacto realizado por Freud pode ser extraído de seu ensaio de 1930,“O mal-estar na civilização". Mesmo que as ideias centrais que Freud elabora nesse texto possam nos parecer esboços teóricos não muito bem-sucedidos, levando em consideração os desenvolvimentos na Antropologia, na Etnografia, na História, na Psicologia e até na própria Psicanálise, sua abordagem mais geral e o modelo a partir do qual concebe o homem e seu 
entorno ganham ainda, ao nosso ver, uma legitimidade poderosa, ao imbricar de forma indissociável o psicológico e o social, o indivíduo e o coletivo, chegando até à imbricação da filogênese e da ontogênese. Assim, por exemplo, em sua investigação sobre as razões pelas quais "é tão difícil para o homem ser feliz" (p. 105), Freud indica três fontes "de que nosso sofrimento provém: o poder superior da natureza, a fragilidade de nossos próprios corpos e a inadequação das regras que procuram ajustar os relacionamentos mútuos dos seres humanos na família, no Estado e na sociedade" (p. 105). Podemos nem levar em consideração toda a argumentação que Freud desenvolve a seguir. O importante é que ele entrelaça natureza, sujeito e cultura de forma indissociável para compreender um estado de coisas. E do modo como ele opera, a velha distinção entre sujeito e objeto nos modelos causais ganha, através de sua compreensão, uma superação significativa, uma vez que, o que seria do campo da cultura e do social - os relacionamentos dos seres humanos na família, no Estado e na sociedade - são de algum modo configurações resultantes também da ação da natureza no corpo, uma vez que as produções sócio-político-culturais têm também uma raiz funda através da qual flui uma vitalidade pulsional, uma das forças responsáveis pela conflituosa dinâmica inerente à produção da história econômica, política, social e cultural. E isso sem mitigar propriamente a autonomia do campo social, que por sua vez, através do processo histórico que suscita, demanda, no corpo, a mesma imperiosidade, isto é, estabelece os mesmos limites e possibilidades determinantes para o seu existir, atuando sobre ele com a mesma imperiosidade com que a natureza atua, a ponto de talvez podermos nomear o cultural como uma segunda natureza do corpo, isto é, do homem. A imperiosidade que o social suscita tem a mesma coloração de urgência que a fome².

O corpo não é apenas um objeto dessas duas forças imperiosas natureza e cultura - mas um agente determinante entre a natureza e a civilização, porque cabe ao homem, para se tornar sujeito, apropriar-se, mesmo que nos seus estreitos limites, da condição de ser responsável diante da natureza e do social e, portanto, o agente principal de sua realização histórica.

A potência com que Freud soube integrar o psicológico e o social teve um impacto, como dizíamos, sobre todo o campo das Ciências Humanas, contribuindo para tornar a Psicologia Social, a nosso ver, algo assim como um campo gravitacional para o qual estas foram atraídas. Benja-

2 Vale aqui lembrar as reflexões de Marcuse (1964/1979) sobre a potência que a cultura tem para a criação de necessidades, a ponto de ele indagar-se, referindo-se especificamente à sociedade industrial de meados do século XX, se haveria ainda alguma necessidade humana genuína, que não fosse construída pela cultura. 
min supõe um jogo de xadrez no campo da Filosofia da História. E devemos ter em mente que não se trata apenas de um embate de ideias, mas, como um bom marxista, Benjamin sabe que se trata de um embate no campo da vida dos homens propriamente dita e de seus destinos, implicando, para além do cultural, o político, o econômico e o social. Isto é, implicando o poder. É talvez o mesmo embate que se trava hoje. Mas, a nosso ver, há um novo anão corcunda atuando nos destinos desses lances - o da Psicologia. Não apenas a máquina que Benjamin monta no campo das ideias funciona em ressonância com a máquina especular que Freud (1900/1976) concebeu na construção de seu modelo de aparelho psíquico, no célebre capítulo VII da "Interpretação dos sonhos" haveria também, na dinâmica própria do campo das ideias, algo assim como um inconsciente, desde onde velhos segmentos ideacionais atuariam, no desdobramento das concepções atuais, numa complexa luta interna onde o novo é sempre uma reorganização das demandas de todas as aspirações humanas construídas ao longo da História. Ao instalar sua máquina especular, que opera em analogia com o modelo psíquico de Freud da primeira tópica, no campo das ideias, de algum modo podemos dizer que Benjamin psicologiza, num certo sentido, a história do espírito, ao permitir entender o campo da história intelectual em analogia ao campo do desenvolvimento psíquico, isto é, lá como aqui, a razão sofre de transtornos.Também no campo da razão o irracional pode irromper, como Adorno bem salienta em seus trabalhos. Esse modo de entender as produções sociais e a própria ideologia já é resultado da força do hífen psicossocial no pensamento contemporâneo.Toda a Escola de Frankfurt trabalhou assim.

Claro que não se trata de reduzir toda a complexidade do campo da Psicologia Social a uma concepção psicanalítica. A aplicação da Psicanálise, enquanto um agregado de teorias construídas ao longo da história dessa disciplina, sobre um determinado contexto a ser estudado reduz em muito o alcance do que ela teria para oferecer ao estudo do fenômeno. Com isso queremos dizer que, a nosso ver, a aplicação da Psicanálise, como um conjunto teórico preestabelecido, sobre qualquer campo de investigações, é um exercício limitado e em nada próximo do pró-

3 Lembremos que Freud utilizou um modelo óptico, isto é, um modelo especular para descrever sua concepção sobre o funcionamento do aparelho psíquico, levando em consideração seus achados sobre a produção onírica. Este modelo devia dar conta de seus quatro achados essenciais em relação aos sonhos: 1. o sonho é um ato psíquico importante e completo; 2 . o que o mobiliza é sempre a realização de um desejo; 3. a forma como se apresenta torna impossível reconhecer esse desejo, dada a deformação promovida pela ação de uma censura psíquica; e 4. além da ação da censura, colabora na formação do sonho a condensação e a representação através de imagens, e por vezes também o cuidado de que o sonho apresente um aspecto racional e inteligente. 
prio exercício psicanalítico. Não se trata, portanto, de aplicar uma teoria psicanalítica no interior do campo da Psicologia Social. Para o modelo e o método psicanalítico serem mais eficazes, a Psicanálise deve se desvestir de sua teoria a ponto de silenciar-se, porque só no silêncio dela o fenômeno que estamos apreendendo da Psicologia Social irá surgir, com sua especificidade. E é próprio da Psicanálise essa espécie de flexibilidade singular de poder ser, ao mesmo tempo, plena e transparente para a apreensão dos fenômenos estudados. O próprio da construção de conhecimentos nesse campo é a constituição de um processo de observação e intervenção cujos desdobramentos são seriamente levados em consideração através de uma reflexão intensa desses fenômenos, num diálogo com o conjunto de teorias que suportam e referenciam a intervenção psicanalítica, mas que outorga ao fenômeno observado o lugar privilegiado, nunca podendo este último ser deslocado ou eclipsado por qualquer concepção teórica tomada a priori. As teorias costumam ser muito ruidosas. Uma Psicanálise mal aplicada, também. Essa propriedade da Psicanálise, tal como aqui a estamos apresentando - a de ver-se impossibilitada de agir com toda a sua potencialidade se reduzida a uma série de construtos teóricos a serem aplicados sobre um fenômeno -, a nosso ver é a mais rica contribuição que esse campo de investigações tem para oferecer para a criação de conhecimentos na universidade. Porque a Psicanálise, tal como a compreendemos, demanda uma intervenção no real, uma prática obrigatória que possibilite uma estruturação do campo de investigação não dada a priori, suficientemente capaz de deixar emergir o conhecimento psicanalítico. As teorias, quando aplicadas no campo da Psicologia Social, costumam traduzir-se em ideologias com muita facilidade, e operar sobre o fenômeno no sentido de instrumentalizá-lo, seja através de sua definição ou de uma ação prática. Mas se Benjamin está certo, se no embate visível existe uma enorme sobredeterminação de aspectos do invisível que operam de maneira irracional, com a capacidade de produzir fenômenos tão perturbadores quanto os violentos totalitarismos que assolaram o século XX, a Psicanálise enquanto modelo e método pode nos auxiliar a indicar a presença deste invisível nos fenômenos sociais estudados, ampliando assim o conhecimento sobre eles. Claro que a produção humana ainda é essencialmente histórica. E claro que compreender como entendemos a História é essencial. Por isso, os lances mais imperiosos nas Ciências Humanas ainda se dão na Filosofia da História, por ser o campo onde se significa a História. Mas o modo como tem se dado o conflito e a produção ideológica em nossos dias pauta-se por uma utilização e tentativa de impactar prioritariamente muito mais os aspectos psicológicos do que propriamente despertar e mobilizar as consciências históricas dos sujeitos envolvidos. A própria fragilidade da política compreendida como jogo ideológico pelo poder, ou seja, a despolitização da política empurrou o embate do poder para o campo da 
Psicologia Social. Basta como exemplo para o que estamos querendo ressaltar o modo como se dão as campanhas eleitorais. Não é o discurso político que as rege, nem sequer as organiza. Mas, sim, o aprimoramento de um discurso e de uma imagem que pretendem implicar cada eleitor, levando em consideração sua psicologia, para falar em termos mais gerais e para sinalizar o que estamos querendo dizer.

Se privilegiamos a Psicanálise como modelo e método, não o fazemos com o intuito de incrementar a psicologização do social. Ao contrário, se é certo que a Psicologia adentrou profundamente a Filosofia da História contemporânea, ou seja, os modos de se conceber a História, nossa proposta é a de utilizar o modelo e o método psicanalítico para auxiliar a localizar os fenômenos sociais estudados no interior da História, e não num marco psicológico exclusivo, uma vez que é exclusivamente a consciência histórica que permite a plena elucidação do fenômeno social. E, se se trata de sujeitos, também neles uma Psicologia Social adequada é aquela que lhes auxilie a se saberem parte da História e tomar para si a possibilidade de atuar nela. Por isso, a Psicanálise não é um fim, mas um instrumento hermenêutico para colaborar na elucidação dos diversos fenômenos abordados.

Se tudo que nós vimos discorrendo sobre a condição do hífen nos dias de hoje, isto é, seu entendimento e o modo como é operacionalizado ${ }^{4}$ é correto, isso nos leva a concluir que a História envolve uma psicologia, que a História é também uma realização psicológica, da mesma maneira como o corpo é uma realização histórica, sem nunca deixar de ser também uma realização da natureza. Nessa área, sempre devemos trabalhar de forma a garantir a multidimensionalidade do fenômeno.

Voltemos a Freud. Quando ele localiza o hífen no natural, no corpo e no histórico, e quando os entrelaça de forma a familiarizá-los indisso-

0 estudo, no momento histórico em que vivemos, que reconhece na técnica seu atributo identificatório mais perfeito, é, antes de mais nada, aplicabilidade, isto é, o desenvolvimento de dispositivos e equipamentos para o aperfeiçoamento do social. Em princípio, na nossa realidade, claro que nada temos a opor a este entendimento. E a Psicologia Social sem dúvida é uma poderosa ferramenta teórico-técnica para aprimorar a formação de profissionais que irão envolver-se nos serviços sociais e nas políticas públicas. Mas, justamente por isso, o estudo pode correr o risco de reduzir-se a um elemento manipulável ideologicamente, e a missão da universidade, nos dias que correm, penso que seja dupla: por um lado, reconhecer sua raiz pública e trabalhar para o aperfeiçoamento da esfera pública e, por outro, lutar pela autonomia necessária para o estudo crítico, isto é, para garantir uma produção capaz de fazer a crítica de toda e qualquer ideologia, o que nos dias de hoje quer dizer, também, de toda e qualquer política pública. Este segundo aspecto também vai, em nosso entender, em direção ao aperfeiçoamento do público, pois a garantia do estudo crítico é também parte da luta por um homem que não seja reduzido à mera inserção numa ideologia determinada, tão própria dos fenômenos totalitários que assolaram tão violentamente o século $X X$, e que hoje podem ganhar uma versão talvez aparentemente mais civilizada, mas não por isso menos violenta. 
ciavelmente, suscitando entre eles relações intercambiáveis dos lugares de cada um desses campos em relação aos outros, dependendo do fenômeno que se estuda - porque é próprio do método e do modelo psicanalítico não estabelecer uma hierarquia fixa e rígida entre os campos da natureza, do corpo e da História para o entendimento dos fenômenos humanos -, isto nunca é feito reduzindo um ao outro ou todos a um campo exclusivo, senão não seriam natureza, corpo e História. Freud nunca é unidimensional. Seu próprio modelo do aparelho psíquico, que é também o modelo psicanalítico, foi montado por ele justamente para dar conta da multiplicidade de determinações existentes na produção humana. Se o fenômeno do sonho é o modelo para a produção do apareIho psíquico, então, justamente por isso, o modelo deve dar conta da sobredeterminação na produção do sonho, a partir de instâncias diferentes e que nunca se reduzem umas às outras, mas que trabalham no interior de uma mecânica de íntimo entrelaçamento. E não apenas isso. O modelo também deve dar conta da multidiversidade com que os fenômenos humanos materializam-se na realidade. $O$ modelo freudiano deve garantir a especificidade do sonhar em relação ao pensar. Tudo isso levou Freud (1916-1917/1976) a propor um modelo em que, como ele diz nas "Conferências introdutórias sobre Psicanálise", "fomos obrigados a ampliar o conceito de 'psíquico' e reconhecer como 'psíquico' algo que não é consciente" (p. 376). Isso quer dizer que o psíquico é sobredeterminado também a partir de um "para além" da consciência. $\mathrm{E}$, assim como o sonho, todos os fenômenos humanos são sobredeterminados desde uma multiplicidade dimensional. Porque o inconsciente não é exclusivamente intrapsíquico, mas talvez a manifestação, de forma bruta, de todo o fazer humano ao longo da História. Freud (1930/1976) ergueu ao estatuto de lei uma estranha e surpreendente hipótese, mas de profundo significado para o que estamos querendo dizer: o que se viveu nunca desaparece. $O$ esquecimento nunca significa a completa eliminação do traço mnêmico.

\footnotetext{
Desde que superamos o erro de supor que o esquecimento com que nos achamos familiarizados significava a destruição do resíduo mnêmico - isto é, a sua aniquilação -, ficamos inclinados a assumir o ponto de vista oposto, ou seja, o de que, na vida mental, nada do que uma vez se formou pode perecer - o de que tudo é, de alguma maneira, preservado e que, em circunstâncias apropriadas (quando, por exemplo, a regressão volta suficientemente atrás), pode ser trazido de novo à luz. (p. 87)
}

O inconsciente é o lugar da memória, e é o próprio Freud (1930/ 1976) que, para ilustrar esse fenômeno da conservação em ação no âmbito psíquico, o aproxima a uma compreensão fantástica de uma Roma aqui apresentada literalmente na condição de uma cidade eterna. 
Permitam-nos agora, num voo de imaginação, supor que Roma não é uma habitação humana, mas uma entidade psíquica, com um passado semelhantemente longo e abundante - isto é, uma entidade onde nada do que outrora surgiu desapareceu e onde todas as fases anteriores de desenvolvimento continuam a existir, paralelamente à última. Isso significaria que, em Roma, os palácios dos césares e as Septizonium de Sétimo Severo ainda se estariam erguendo em sua antiga altura sobre o Palatino e que o Castelo de Santo Ângelo ainda apresentaria em suas ameias as belas estátuas que o adornavam até a época do cerco pelos godos, e assim por diante. Mais do que isso: no lugar ocupado pelo Palazzo Caffarelli, mais uma vez se ergueria - sem que o Palazzo tivesse de ser removido - o Templo de Júpiter Capitolino, não apenas em sua última forma, como os romanos do Império o viam, mas também na primitiva, quando apresentava formas etruscas e era ornamentado por antefixas de terracota. (p. 88)

Os etruscos constituem-se num aglomerado de povos que se instalaram na península itálica há mais de 3000 anos. A cidade eterna que Freud supõe condensa toda a história humana numa imagem arquitetônica em que nada é ruína, no sentido de perder quase que completamente sua vitalidade sígnica. Tudo o que foi ainda está vivo e demanda na cidade eterna construída por Freud. A cidade eterna é o hífen, origem das variadas manifestações humanas, em todos os campos do seu fazer. E, por isso, todas as realizações humanas, o desenvolvimento de cada um - que também é realização humana -, a produção científica, a técnica, as Ciências Humanas, a literatura, a poesia e as demais artes, são todas elaborações sobredeterminadas desta gigantesca e condensada memória viva, que no seu pulsar constitui a própria História, terreno no qual se enraízam todas as construções humanas. E se dizemos que se enraízam, é num sentido de via dupla: toda construção é mais uma implantação, é mais uma edificação na cidade eterna. E, por outro lado, toda edificação é uma construção erguida a partir dos elementos e da vitalidade colocada à disposição pelo estado de coisas na cidade eterna. O novo não supera o velho. Entre o velho e o novo, a dinâmica é mais de estrutura. A História não é diacrônica.

Benjamin (1940/1971), nas suas Teses da Filosofia da História, também construiu uma imagem que de algum modo nos permite aprofundar nossa compreensão da História, trabalhando em ressonância com a imagem da cidade eterna montada por Freud. Diz assim a sua tese de número IX:

Minha asa está pronta para o voo,

Voo voluntariamente para trás,

Porque se eu me detivesse algum tempo para viver,

Teria pouca ventura.

Gershom Scholem, Saudações de Angelus 
Existe um quadro de Klee que se intitula Angelus Novus. Vê-se nele um anjo, ao que parece, no momento de distanciar-se de algo sobre o qual fixa o seu olhar. Tem os olhos arregalados, a boca aberta e as asas estendidas. $O$ anjo da História deve ter esse aspecto. Seu rosto está voltado para o passado. Naquilo que para nós se mostra como uma sucessão de acontecimentos, ele vê uma catástrofe única, que acumula sem cessar ruína sobre ruína, a depositar-se sob os seus pés. $\mathrm{O}$ anjo gostaria de deter-se, despertar os mortos e recompor o despedaçado. Mas uma tormenta desce do Paraíso e provoca um redemoinho em suas asas, e é tão forte que o anjo não pode firmá-las. Essa tempestade o arrasta irresistivelmente para o futuro, ao qual dá as costas, enquanto o acúmulo de ruínas sobe diante dele, em direção ao céu. Tal tempestade é o que chamamos progresso. (p. 82 , tradução nossa $)^{5}$

Em Benjamin, resgatamos a dimensão dinâmica e processual que é inerente à História - o dinamismo que é inerente ao hífen que nos interessa. A História não é propriamente a cidade eterna, mas o que é possível apreender no aqui-e-agora, na ininterrupta tormenta do progresso que, desde o Paraíso, sopra em direção ao futuro. Freud constrói a sua cidade eterna preservando-a do fluir da História. A cidade eterna é uma espécie de palimpsesto onde todas as múltiplas camadas podem estar à disposição, manifestamente. Benjamin introduz o elemento dinâmico. $\mathrm{E}$, então, a imagem da ruína deve novamente ser levada em consideração. Porque tudo que, em Freud, é edificação, em Benjamin, que tem o olhar fixo no Paraíso, isto é, no território das expectativas de aperfeiçoamento e até de redenção do homem e dos fenômenos humanos, é visto como ruína, a demandar reparação. Cada construção, cada morto, demanda. A cidade eterna transforma-se no terreno não apenas de uma memória viva, mas de uma demanda intensa feita ao anjo da História, que a tempestade do progresso arrasta. A demanda é tão intensa que o anjo gostaria de se deter e, levando seriamente em consideração essa demanda de mortos e ruínas, edificar uma reparação. Mas a tempestade não dá tempo. $\mathrm{E}$ tudo o que o anjo pode construir em seu ato reparatório é talvez um fragmento mal acabado que imediatamente a seguir, dada a força da tormenta - que nada mais é do que o suceder do tempo -, transforma-se em nova ruína depositada sob os seus pés, isto é, numa nova demanda a juntar-se ao grito desesperado das ruínas. E seria esse grito desesperado a realização da História.

5 Na apresentação do livro Pensamento cruel - Humanidades e Ciências Humanas: há lugar para a Psicologia?,Maria Helena S. Patto e João A. Frayze-Pereira (2007), seus organizadores, também trabalharam com esta imagem para pensar a prática da Psicologia. E eles agregam à imagem erguida por Benjamin mais uma obra de Klee, $O$ saltimbanco, para salientar o difícil equilíbrio da prática do psicólogo em sua ação crítica, para possibilitar uma leitura transformadora. 
A nosso ver, as imagens construídas por Freud e Benjamin podem complementar-se e, nessa realização, fortalecer nosso entendimento do hífen tanto em sua ação multidimensional quanto em sua organização. Porque do hífen emergem todas as produções humanas e, por sua vez, todas as produções humanas ressignificam e reorganizam o hífen. Em alemão, existe um termo que talvez seja o que mais se aproxima para dar conta da operação no interior do hífen entre o psíquico e o social: tratase da palavra Weltanschauung, que nós poderíamos traduzir como visão de homem/visão de mundo ${ }^{6}$ e que, como um conceito englobante, deve apontar ao mesmo tempo para o elemento estável e dinâmico que lhe é inerente. Estável porque, como um conceito englobante, acompanha todas as realizações do homem, como um sentido capaz de abranger em compreensão todo o estado de coisas da realização humana, abarcando algo assim como a história das meditações do homem sobre o homem. Toda produção humana se enreda em sentido. E, no aspecto dinâmico, fazemos referência à própria potencialidade do sentido, que é específica em relação a cada desdobramento das realizações humanas. Só que aqui não mais nos referimos ao sentido na sua dimensão abrangente, mas à concretude específica da atribuição de um sentido singular. Dizíamos antes que o hífen é manifestação de todo o fazer humano ao longo da História, e o aproximamos do inconsciente como sua manifestação em forma bruta e não lapidada. A Weltanschauung, isto é, as diversas visões de mundo e de homem e as ideologias que a Filosofia da História foram depositando ao longo da História, bem como as que ainda são construídas, seriam justamente as operações de lapidação que são constituídas no hífen, através da ação humana.

O que nós ganhamos ao integrar as imagens de Freud e Benjamin é que, em primeiro lugar, nos parece que fortalece o terreno da História como campo no qual trabalhamos o hífen psicossocial. Em segundo lu-

6 Freud dedicou a Conferência XXXV das Novas conferências introdutórias sobre Psicanálise(1933/1976), a refletir sobre se a Psicanálise poderia oferecer-se aos homens como uma nova Weltanschauung, como alternativa às Weltanschauungs provenientes dos campos religioso e filosófico. E ele enfatiza o pensamento de que não, de que a Psicanálise não pode se constituir como uma Weltanschauung alternativa às provenientes da Religião e da Filosofia. 0 elemento que ele utiliza para distinguir a Psicanálise desses campos é a íntima conexão que vê existir entre a Psicanálise e a Ciência. E pensa que a Ciência é ainda muito jovem para constituir-se numa Weltanschauung por si própria. Por outro lado, Freud argumenta que toda Weltanschauung, isto é, toda visão de homem e de mundo é constituída em torno de elementos de ilusão, que passam a fazer parte destas visões. E atribui à Psicanálise "a submissão à verdade e a rejeição às ilusões" (p. 220). Por isso, a Psicanálise não apenas é incapaz de oferecer-se como um consolo para os homens na forma de uma Weltanschauung, como justamente por isso é uma poderosa ferramenta crítica para mostrar os limites e possibilidades que estão contidos em cada Weltanschauung e seus desdobramentos em ideologias, tal como viemos defendendo no uso do modelo e do método psicanalítico. 
gar, dada a tensão que se estabelece entre as duas imagens, entre edificações e ruínas, entre o elemento preservado e ativo destacado por Freud e o elemento frustrado e desapontador destacado por Benjamin, dessa tensão pode emergir uma produção no campo psicossocial que seja ao mesmo tempo um resgate de memória, uma ressignificação e um ato reparatório. Ou seja, uma construção no sentido mais pleno do termo, uma vez que envolve memória e reparação. Achamos importante apontar que a imagem de Benjamin é poderosa o suficiente para que também a entendamos não apenas como um constructo erguido para significar o trabalho da História enquanto práxis e estudo, mas, a nosso ver, essa imagem de algum modo também consegue acolher os processos de reconstrução pessoais que cada homem deve realizar. Porque, nos processos de reconstrução pessoais, um anjo da História particular - se quisermos usar a imagem que Benjamin põe em cena olhando através do quadro de Klee - está em ação, com os mesmos olhos arregalados, a mesma boca aberta, a mesma tensão nas asas e, principalmente, a mesma implicação com o tempo: tudo o que ele dispõe é do passado, apresentado ao mesmo tempo - se integrarmos as imagens de Freud e de Benjamin - na forma de memória e ruína, a demandar o seu ato de construção pessoal, modo como o futuro se realiza. Carlos Drummond de Andrade alude também a esse anjo pessoal na primeira estrofe de seu Poema de Sete Faces:

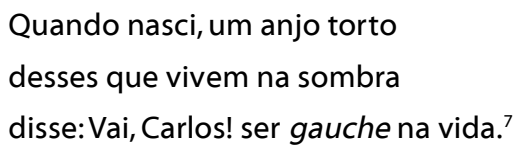

A voz poética é demandada desde o seu nascimento, a partir de suas origens e da sombra, a construir uma determinada concepção de vida, visão de homem e de mundo. Ser gauche não é bem uma opção, tampouco é propriamente uma vestimenta obrigatória, algo assim como uma visão de mundo já pronta e acabada que Carlos nada mais teria que fazer a não ser passar a utilizar. É mais algo assim como uma demanda mesmo, uma espécie de força gravitacional proveniente do estado de coisas em sua origem, capaz de organizar seu modo singular de ver a si e ao mundo. Ser gauche não é uma opção, mas tampouco é um destino para Carlos. É, como dissemos, uma demanda, algo assim como uma imperiosidade suscitada desde as sombras da origem de Carlos. $O$ desdobrar de Carlos não é arbitrário. Se, na forma poética singular, a herança literária, isto é, a memória das formas literárias empresta o material para a lapidação do poema singular, num processo que Harold Bloom (2002)

7 Os poemas de Carlos Drummond de Andrade com que trabalhamos aqui foram todos extraídos da Antologia poética (1987) organizada por ele. 
cunhou como "angústia da influência" e que enreda de forma complexa permanência e inovação, tradição e ruptura, Drummond aloca freudianamente essa angústia de influência num terreno biográfico, familiar $^{8}$,e não exclusivamente estético. É desde o seu nascimento que o anjo torto o demanda, com a mesma angústia paradoxal que Harold Bloom aponta. Porque ser gauche não é fácil. Ser gauche significa, de algum modo, oporse. Mas, como escutar uma demanda por opor-se, sem opor-se a ela? É quase um impossível.Se Carlos obedecer ao anjo, não será propriamente um gauche. Gauche que é gauche não escuta os anjos. Mas se não escutar o anjo, será um gauche e, neste caso, estará sob o imperativo da demanda desse anjo torto, dessa influência de origem. O paradoxal invocado pelo poeta é importante como manifestação da força da origem que o impele a ser o que ele virá a ser, na sua meditação sobre si e o mundo. Carlos escuta ao mesmo tempo uma demanda de tradição e ruptura, de memória e construção. Diz ele, em Retrato de Família:

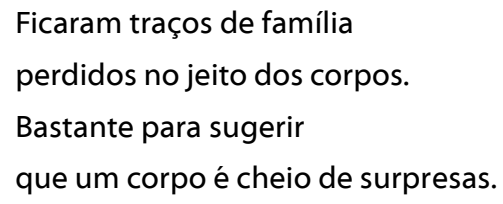

Traços de família e surpresas é do que é feito o jeito de um corpo, tal como traços de família e surpresas fazem o corpo do poema. Porque o poema é um retrato de família, tal como o corpo e suas realizações. O que o poeta irá fazer, o que irá desdobrar em forma poética, o vértice específico a partir do qual trabalhará seus poemas e, através dos poemas, trabaIhará suas origens, não é aleatório nem tampouco destinado, no sentido de já dado, mas uma construção tão embrenhada de paradoxo, tão ao mesmo tempo atrelada a uma origem e aberta para o novo como o imperativo de ser gauche.

Não deve nos surpreender o paradoxal, se levamos em consideração o modelo freudiano. Nele, não apenas o fenômeno psíquico é maior do que a consciência, isto é, as determinações do que somos estão para além de nós, mas neste modelo é inerente à noção de inconsciente a existência dos opostos. O paradoxo não é uma exceção - nas formações psíquicas é uma regra. Na cidade eterna, o diálogo entre os edifícios pode ser bem ruidoso e nem toda essa arquitetura fala a mesma língua. A memória é uma Babel, tanto em seu sentido macroscópico quanto em sua dimensão microscópica, ao nível da história familiar de cada um. A som-

8 Em Confidência do Itabirano, bem como nos poemas da seção A família que me Dei, da Antologia Poética, torna-se mais explícito que a origem na qual o poema se enraíza e da qual é um desdobramento ao mesmo tempo de submissão e criação é a família e o entorno dela, Itabira. 
bra do poema, desde onde o anjo torto demanda, não é propriamente uma ausência de luz, mas uma claridade indefinida, uma radiação ainda a ser desdobrada nas sucessivas polarizações, isto é, nas concentrações do aqui-e-agora de que é feita a vida. $O$ paradoxo do mundo de Carlos não ficaria resolvido se Carlos fosse Raimundo. Verdade que pareceria mais harmonioso, porque Raimundo rima com mundo:

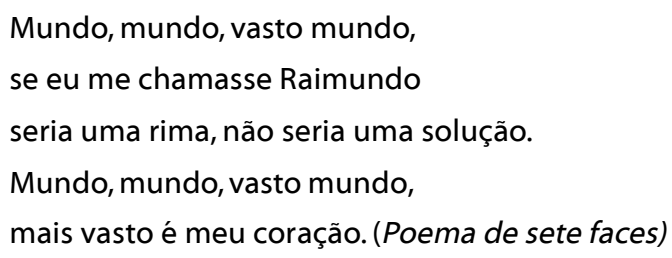

Se Carlos fosse Raimundo, ele e o mundo estariam em melhor acordo. Mas isso, diz Carlos, só na rima. Porque na vida, entre coração e mundo instala-se um paradoxo, ou um conflito, que é outra maneira de falar do paradoxo - a maneira psicanalítica de abordá-lo. O mundo é vasto, a origem é vasta, mas o coração, diz o poeta, é mais vasto ainda. E é exatamente desde esse coração que o anjo torto da origem demanda, atuando como uma sombra sempre presente e impossível de pular.

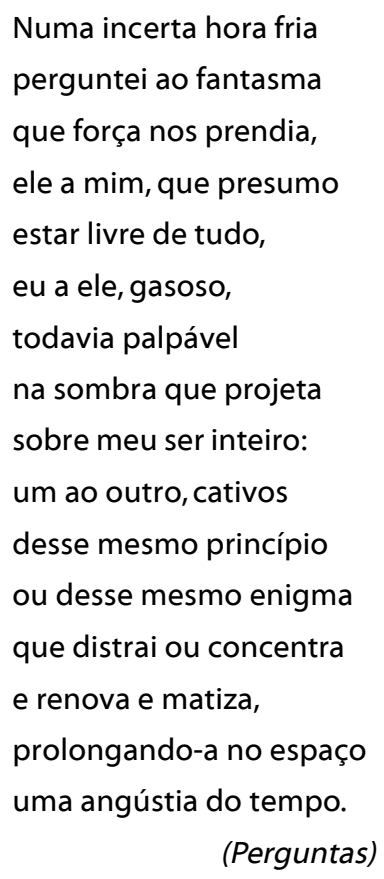

O anjo torto aqui assume o re-trato de um fantasma, tão demandante quanto o primeiro e, ao mesmo tempo, capaz de renovar e matizar 
como o primeiro. Como o anjo, o fantasma é o enigma que desdobra e enraíza o poema. Ele é o próprio suceder da voz poética nas polarizações do aqui-e-agora a que fazíamos referência antes, ou como essa voz diz melhor, na prolongação no espaço de uma angústia do tempo. Neste mesmo poema, Carlos Drummond de Andrade 9 nos permite sair do anjo pessoal e voltarmos para o anjo da História, de Benjamin. Porque a voz poética faz ao fantasma uma última pergunta:

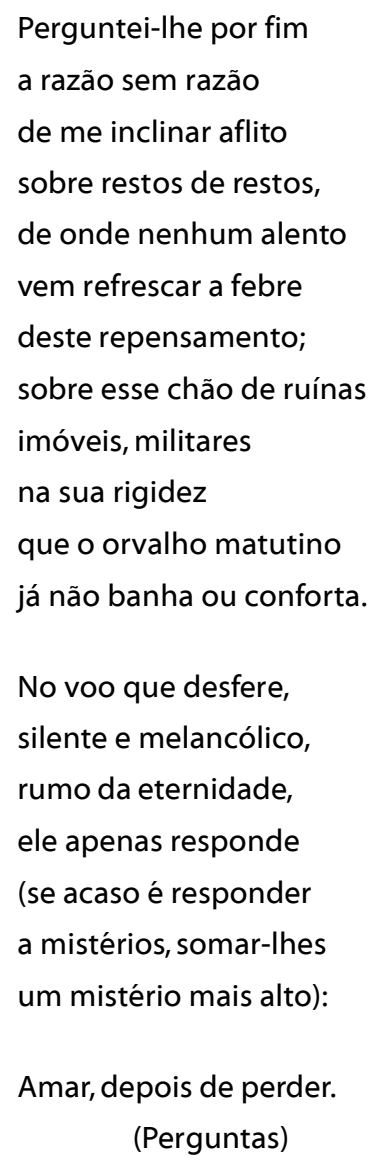

O fantasma de Carlos Drummond de Andrade atua como o anjo de Benjamin. Ambos são atormentados e ambos operam numa paisagem tão semelhante. Ambos produzem e deixam uma paisagem tão análoga, ambos demandam reparação - amar, depois de perder. Se o anjo de Benjamin, diante da catástrofe, quer recompor o despedaçado e acordar os

9 No nome do poeta, vemos inscrito o paradoxo que ele desdobra em tantos poemas: o de ser Carlos nos laços de família tão explicitados na preposição de, que o ata aos Andrade. Mas como dói! 
mortos, o fantasma de Carlos Drummond de Andrade opera nesse repensamento, que nada mais é do que a razão sem razão de se inclinar aflito sobre restos de restos. Em Benjamin, essa reconstrução será mais uma ruína a juntar-se às ruínas. Em Carlos Drummond de Andrade,é uma febre, aqui exposta como poema. O que Benjamin e Drummond nos permitem problematizar nada mais é do que esse campo de estudos tão promissor que atualmente se denomina de transmissão geracional, e que emerge dessa hipótese tão cara a Freud, sobre a existência de uma analogia familiar nos desenvolvimentos da ontogênese e da filogênese. Talvez o que levou Freud para este tema foi a própria vinculação profunda que ele viu ocorrer entre sua biografia pessoal e a psicanálise que ele criou. Drummonianamente, poderíamos dizer que a Psicanálise é o resultado da febre de Freud, ao inclinar-se aflito sobre restos de restos de sua história pessoal. Na Interpretação dos Sonhos, Freud opera como Dante na Divina Comédia. Não apenas ele é ao mesmo tempo autor e personagem principal, mas também uma travessia difícil é tematizada. Dante, atravessando toda a imensidão do mundo eterno, o Inferno, o Purgatório e o Paraíso, irá encontrar Beatriz. Freud traz todo esse vasto mundo para a cena familiar. Inferno, Purgatório e Paraíso que devem ser atravessados para encontrar o quê? Um Freud desdobrado em Psicanálise. Laços de família não apenas integram sua produção à sua biografia, mas são os próprios laços de família que se renovam e se matizam em Psicanálise. Na correspondência de Freud a Fliess (1887-1902/1986), temos acesso a fragmentos da autoanálise de Freud. E o que vislumbramos é que não é apenas a ambivalência afetiva de Freud em relação a seus pais o pilar do conflito psíquico que ele atravessava nesse período. Ou melhor, o conflito afetivo materializa-se numa complexa rede ideacional que embaraça todo o núcleo familiar, que também é via de passagem ou de acesso aos seus antepassados e seus emaranhados ideacionais.

Em 1900, mesmo ano da publicação da Interpretação dos Sonhos, são re-descobertas as leis da hereditariedade de Mendel, que ele apresentara num trabalho à Sociedade de História Natural de Brünn em 1865. Mendel estudou estas leis trabalhando com os hibridismos de plantas o que the possibilitou determinar o número de formas diferentes com que se manifestam os brotos das plantas híbridas -, ou arranjando-as de maneira tal que dessem origem a formas predeterminadas de brotos. Ele provou que, na variação de certos aspectos da planta, traços de gerações passadas manifestavam-se no broto, ainda que esses traços estivessem invisíveis na geração anterior, atuando de modo recessivo na ordem genética. Nas palavras dele, certos caracteres eram apenas "dominados" por outros caracteres numa determinada geração. A partir do que Mendel observava em suas ervilhas, a dúvida que persistia era sobre como explicar esse desaparecimento de uma característica numa geração e o seu reaparecimento na geração seguinte. Ee a essa dúvida que a hipótese de 
dominância e recessividade responde. Freud não pensa de modo muito diferente quando estuda a constituição do aparelho psíquico. Aqui também, se se quer, Freud realiza um estudo genético. Porque o estudo das características pessoais leva em consideração as interações com os membros familiares. E essa interação não é exclusivamente de ordem afetiva, ou melhor, o afeto nunca é, na sua forma pura, o elemento que transita entre todos os membros da família. Para Freud, todo traço mnêmico é um híbrido de ideias e afetos. A ideia qualifica o afeto, e assim o conflito psíquico nunca se reduz a um conflito afetivo. Ele é sempre um conflito ideacional colorido por um afeto. É o próprio Freud quem diz que o afeto nunca é reprimido. $O$ que é reprimido é um complexo ideacional. $O$ inconsciente não é constituído por afetos, mas por ideias, isto é, elaborações, expectativas, pontos de vista, recordações, impressões. Claro que qualquer manifestação ideacional é carregada de afeto, e é este afeto que pode tornar o núcleo ideacional desprazeroso e, portanto, sujeito à ação da repressão. Mas, de qualquer maneira, aquilo que fica reprimido e nunca é excluído ou apagado é sempre um componente ideacional. E desde o inconsciente, são núcleos ideacionais que atuam "recessivamente" na determinação de manifestações psíquicas posteriores. E assim nos homens, como nas ervilhas, certas características, mesmo que não se manifestem diretamente, não desaparecem, induzem características posteriores e às vezes tornam a manifestar-se em momentos posteriores da vida.

O conflito psíquico se suporta na ambivalência afetiva entre amor e ódio, mas isso é uma afirmação geral. Na singularidade de cada fenômeno, o modo como o amor e o ódio se manifestam é sempre uma experiência vivida - em família, uma experiência na qual os aspectos ideacionais de todos os membros, crianças e adultos, estão em atividade. Claro que o aspecto ideacional na criança opera numa lógica e até talvez com um estatuto diferente do adulto, mas essa diferença não significa a anulação de sua elaboração ideacional,elaboração esta que obviamente deve adquirir um lastro para a sua operação que é proveniente do núcleo familiar em que está inserida a criança. Lacan diz que o inconsciente se estrutura como uma linguagem. Não é muito diferente do que estamos dizendo. Toda família é uma linguagem. Mas isso não quer dizer que ela seja apenas uma estrutura. Ela é também um novelo ideacional, uma cidade eterna. A criança aprende em família e através da família. Abraham e Torok (1994), no livro The Shell and the Kernel, salientam o fato de a criança estar apegada e perceber os gestos da mãe, seus atributos psíquicos e suas palavras. Mais do que perceber e estar apegada, mãe e criança constituem uma unidade dual da qual a criança tem que se separar, carregando em torno de si, de acordo com os autores, toda uma série de rastros, o fantasma que vincula, de alguma maneira, o estar aqui-e-agora com essa unidade dual original. As leituras desses autores permitem compreender a operação ideacional da criança como sendo uma operação 
com elementos advindos do novelo ideacional familiar, permeada por esse novelo. Vale a pena salientar aqui que esse novelo ideacional também se enraíza nas experiências de vida da família e, portanto, dele fazem parte pontos de vista, expectativas, impressões e o registro das histórias vividas pelos membros também nas distantes gerações desse núcleo familiar. A família é também um novelo de histórias a partir do qual cada um deve organizar-se e ganhar autonomia. Como Carlos, cujo poema é uma elaboração sobre suas origens, os Andrade. A construção de nosso ser, essa operação ontogenética, é feita com o material familiar, em torno desse material, que é a filogênese de cada sujeito. Nós todos somos produtos psíquicos de uma regressão infinita de histórias familiares. Freud destaca na cidade eterna a presença de todas as edificações construídas ao longo da história. As edificações seriam essas histórias familiares. Benjamin destaca o caráter de ruína. As ruínas seriam também essas histórias familiares. Toda história familiar carrega também silêncios, pontos de suspensão, hífens e mutismo. Isso não quer dizer que algo se suprime; nada se suprime. Algo apenas se silencia, se isola e pode ganhar a qualidade de segredo. Na condição de silêncio, de mutismo, o conhecimento se desconhece. $\mathrm{Na}$ qualidade de segredo, o desconhecimento se conhece. Ambos operam na rede ideacional da criança. Ambos suscitam a febre a que Drummond se refere em seu poema. Ambos fazem parte da vastidão do coração. Ambos fazem parte da linguagem da família, atuando portanto como forças determinantes dos limites e possibilidades das operações ideacionais a que todos os membros da família estão submetidos, inclusive a criança. Se o silêncio e o segredo ganham uma forte amplificação no novelo ideacional da família, cada um dos membros vê reduzida a sua possibilidade de nomeação tanto sobre o que se passa em família quanto sobre si próprio e sobre o mundo que o rodeia. Assim como na imagem de Benjamin um anão corcunda determina os lances do jogador, e no poema de Drummond um anjo torto determina a visada de vida da voz poética, os silêncios, os segredos, falam tanto quanto os novelos ideacionais no romance familiar que cada um ergue na construção de seus projetos identitários. Tanto no silêncio quanto no segredo está presente um elemento traumático, para utilizarmos um termo que é importante na Psicanálise. Se Freud soube imprimir à Psicanálise um caráter etiológico, isto é, uma vinculação com uma origem para a compreensão do fenômeno psíquico, na origem da Psicanálise Freud outorgou ao trauma o estatuto de origem do sintoma psíquico. Ali, a Psicanálise surgiu. O trauma psíquico é uma comoção psíquica. Ferenczi (1933/1981) lembra que a palavra alemã erschütterung, comoção psíquica, vem de schutt, ruína, compreendendo a destruição, a perda da própria forma. Em Estudos sobre a Histeria, o primeiro trabalho psicanalítico de Freud (1895/ 1976), o trauma assume em diversos momentos essa condição de origem do conflito psíquico, do sintoma. Ali, o trauma é entendido como 
um evento advindo do real, como um choque na experiência real capaz de estremecer as defesas do eu. Mas, à medida que Freud foi se aprofundando em sua compreensão da realidade psíquica, o estatuto do real foi, por assim dizer, sendo absorvido ou englobado pelo da realidade psíquica. Freud nunca silenciou propriamente a força do real. Isso nós podemos ver em todos os casos clínicos, em que os aspectos do real são seriamente levados em consideração por ele. Mas Freud outorgava também à realidade psíquica um papel ativo na constituição do conflito. Podemos até afirmar que responsabilizar a realidade psíquica pelo conflito é uma das características básicas da Psicanálise e, a nosso ver, isso se deve não apenas a Freud entender que a realidade psíquica se constitui a partir de um suporte pulsional, mas também talvez porque responsabilizar cada sujeito por seu sintoma seja uma etapa importante da terapêutica, no sentido de possibilitar a superação do sintoma. Em todo caso, é inerente aos textos psicanalíticos de Freud, quando vistos em seu conjunto, uma certa ambiguidade em sua posição em relação à ressonância do real na constituição psíquica e, mais especificamente, na noção de trauma. Se, por um lado, Freud avança no sentido de dar uma ênfase maior à realidade psíquica, por outro lado essa realidade é constituída em resposta ao real. É isso que nós vemos apresentado em "Além do princípio do prazer" (1920-1921/1976), onde a angústia, a consequência imediata do trauma, funciona como um sinal organizador de todos os mecanismos de defesa do ego, isto é, ela é estruturadora da realidade psíquica. E mais: toda essa ênfase que Freud dá à filogênese nada mais é do que salientar o fator determinante dos elementos extrapsíquicos que, em Freud, de algum modo também devem se constituir numa espécie de história psicológica para agir na psicologia de cada um. Assim é, por exemplo, em seus estudos em "Totem e tabu" (1913/1976), onde a angústia de castração e o próprio complexo edípico, que em princípio são para Freud invariáveis da constituição psicológica de cada um, são determinados pela história psicológica na qual ficam enredados os processos históricos, morais e religiosos dos homens, ate uma mítica horda primitiva na qual teria se dado o parricídio originário, cena histórica e origem de uma história psicológica singular dos homens. Isso quer dizer que o novelo ideacional é uma filogênese, ou uma história psicológica que atravessa gerações e constitui-se num patrimônio psíquico da elaboração de cada sujeito: os Andrade é o patrimônio filogenético para a construção ontogenética de Carlos, o que significa que os Andrade são tanto a reserva sócio-cultural-econômica de Carlos quanto o seu trauma. E como o coração dele é mais vasto do que todo esse mundo, isto é, cabe nele todos os Andrades e um algo além, Carlos e esse mundo não rimam em perfeição - para a sorte e azar de Carlos. O trauma é inerente à elaboração, como o processo de construção pessoal é inerente ao ato de reparação. 
Voltemos a Benjamin (1969/1980): num texto dedicado à obra do escritor russo Nikolai Leskow (1831-1895), ele reflete atentamente sobre a arte de narrar e o trabalho do narrador:"apresentar um Leskow como narrador não significa aproximá-lo de nós - significa, antes, aumentar nossa distância em relação a ele" (p.57). O que Benjamin ressalta no início desse ensaio é que

a arte de narrar caminha para o fim. Torna-se cada vez mais raro o encontro com pessoas que sabem narrar alguma coisa direito...É como se uma faculdade, que nos parecia inalienável, a mais garantida entre todas as coisas seguras, nos fosse retirada. Ou seja: a de trocar experiências. (p. 57)

Benjamin ressalta a intimidade existente entre narrativa e experiência, e agrega:"a experiência caiu na cotação" (p. 57). Ele ilustra essa desvalorização tomando como exemplo o jornal:"qualquer olhada aos jornais comprova que ela [a experiência] atingiu novo limite inferior, que não só a imagem do mundo externo, mas também a do mundo moral, sofreu da noite para o dia mudanças que nunca ninguém considerou possíveis" ( $p$. 57). Ao trazer à cena os jornais para falar sobre o estado de coisas do mundo externo e do mundo moral, Benjamin, a nosso ver, não apenas está problematizando esse estado de coisas, mas também o modo como ele é representado, ou melhor, o meio através do qual é representada a imagem do mundo externo e do mundo moral. McLuhan salientou que $o$ meio é a mensagem. E Benjamin parece aqui salientar que os jornais, isto é, os meios de comunicação centrais sobre o mundo externo e o mundo moral, não são propriamente instrumentos para a troca de experiências, não são propriamente territórios onde se possa pôr em operação com sua plena força o essencial do narrador, isto é, a narrativa. $O$ jornal pode informar, pode opinar, pode demandar, pode vender, pode dirigir, mas não narrar. E, por isso, o jornal não se constitui num campo através do qual os homens possam ganhar experiência. O que, pelo desdobramento do ensaio, quer dizer que a troca de informações veiculada pela mídia não abre o homem para uma transformação pessoal - atributo, para Benjamin, da situação de troca de experiências. Ao contrário, as informações que são veiculadas pelos jornais, as imagens do mundo externo e do mundo moral, encerram o homem na situação externa e no mundo moral em que ele já se encontra inserido: o jornal aprisiona o homem ao mundo externo e moral, sem lhe permitir a abertura que a narrativa e a experiência trazem consigo. Mas Benjamin continua:

com a guerra mundial, começou a manifestar-se um processo que desde então não se deteve. Não se notou, no fim da guerra, que as pessoas chegavam mudas do campo de batalha - não mais ricas, mas mais pobres em experiência comunicável? O que dez anos mais tarde desaguou na mare de livros de guerra era tudo, menos experiência que anda de boca em boca. E isso não era 
de estranhar. Pois nunca as experiências foram desmentidas mais radicalmente do que as estratégicas pela guerra de posições, as econômicas pela inflação, as físicas pela batalha de material bélico, as morais pelos detentores do poder. Uma geração que ainda fora à escola de bonde puxado a cavalos ficou sob céu aberto numa paisagem onde nada permanecera inalterado, a não ser as nuvens e, debaixo delas, num campo magnético de correntes e explosões destruidoras, o minúsculo, frágil corpo humano. (p. 57)

Nem sequer a "maré de livros" consegue pôr em circulação a experiência. Tudo se transformou de um modo bem violento, "num campo magnético de correntes e explosões destruidoras" e, no entanto, nada parece dar conta da narrativa dessa transformação - nem os jornais, nem a maré de livros. Benjamin está falando de um transtorno ocorrido nas primeiras décadas do século XX - um transtorno que envolve a modernidade, a vida urbana, a tecnicização e uma guerra. E o modo como ele lida com esse transtorno sugere que, na história dos homens, podem acontecer fatos que operam em analogia com aqueles que Freud detectou e que promovem a comoção psíquica no sujeito individual. Se, como afirma Ferenczi (1933/1981),"o trauma impacta o sujeito, fragilizando o seu sentimento de si, sua capacidade de resistir, de atuar e de pensar em defesa do próprio eu, promovendo uma comoção que não pode ser superada", nem por uma transformação do mundo circundante, no sentido de afastar a causa etiológica da comoção, nem tampouco através da produção de uma elaboração capaz de superar a comoção, Benjamin sugere que, na História, o trauma silencia a experiência, ou melhor, a elaboração de uma vivência, que é o modo como os fatos vividos podem se realizar em experiência, ou seja, em vida elaborada, num patrimônio pessoal, resultado das aventuras de cada um no campo da vida. De acordo com a lógica do texto de Benjamin, é possível viver e não ganhar experiência. Esse é um transtorno pessoal. Mas Benjamin, realizando uma arqueologia social, encontra um fator etiológico mais profundo, isto é, mais amplo, para essa incapacidade de elaborar a vida em experiência: os transtornos são pessoais, mas o fator etiológico é um estado de coisas no social: o desaparecimento do narrador e da narrativa promovido por um poder tecnocrata. Os soldados chegaram da primeira guerra mundial, de acordo com ele, mudos. E os jornais e a maré de livros não puderam contribuir para a superação desse silêncio. Uma comoção atingiu a História, isto é, as vivências humanas veem afetadas a sua possibilidade de elaboração. $E$ todo um grupo social fica encerrado no silêncio, na incapacidade de transformar a vivência em experiência. Benjamin traz assim a noção de trauma - palavra originária do campo da Medicina e utilizada por Freud para dar conta das comoções psíquicas - para o campo da História. Mais uma vez, nós podemos acompanhar como observações da clínica psicanalítica podem ser utilizadas no estudo dos fenômenos sociais. Nos dias de hoje, 
são diversos os autores que trabalham com a noção de trauma na História $^{10}$, e observam a reação de grupos sociais a eventos violentos, a partir deste referencial. Mas ainda Benjamin, nesse texto, pode ser uma referência para este campo de estudos. Porque na sua agudeza reflexiva, ele sabe nomear que a catástrofe de uma guerra ou de eventos sociais violentos pode ocasionar bem mais do que as gigantescas perdas materiais e humanas, que sempre estão envolvidas nesses acontecimentos. Podem acarretar uma comoção psíquica do grupo, isto é, um transtorno no modo como se representam e representam o mundo ao redor, e até na própria possibilidade de representação de si e do mundo, com um impacto intenso na história desse grupo social, a ponto de delinear as determinações básicas do modo como esse grupo social irá comportar-se historicamente. No caso que Benjamin estuda - as comoções históricas das primeiras décadas do século $X X \mathrm{v}$, trouxeram consigo o emudecimento da narrativa, a impossibilidade de representar o vivido, portanto, de superá-lo com uma transformação de si. Freud (1917/1976), em "Luto e melancolia",destaca que nos processos melancólicos, isto é, naqueles em que um acontecimento doloroso, uma perda, não é possível de ser superado através de um processo de luto, "a sombra do objeto cai sobre o ego" (p. 281), isto é, o ego fica refém do objeto perdido e promotor da angústia, suscitando uma fragilização da coesão das formações psíquicas e a emergência de uma desorientação. É desta desorientação que Benjamin trata, num nível coletivo. O grupo social pode perder as instâncias narradoras, aquelas capazes de dar sentido à experiência num para além do mero registro ideológico, que nunca dá plenamente conta da comoção grupal que o choque da História suscita. Os jornais e livros a que Benjamin se refere apenas põem em circulação uma imagem da realidade que coage o grupo social, no sentido de ficarem encerrados, reféns dessa realidade, isto é, esses jornais e livros não são espaços de elaboração, podendo ser, do modo como Benjamin os entende, instrumentos da mesma batalha e, portanto, ferramentas do"campo magnético de correntes e explosões destruidoras".

Se sugeríamos anteriormente que o hífen da Psicologia Social é o lugar da memória e das operações com ela, isto é, o modo como se efetiva uma Psicologia e um Social específicos, ou o modo como se entrelaçam natureza, corpo e cultura, um trauma social nada mais é do que uma comoção no hífen.É isso que Benjamin salienta ao tratar do silenciamento da experiência. O que parece transtornado é o trabalho com a memória. Benjamin, no mesmo texto, apontará para o esvaziamento da noção de

10 Uma coletânea importante de estudos interdisciplinares sobre o impacto traumático de violências contra grupos humanos é Cultures under siege: collective violence and trauma (Robben \& Suarez-Orozco, 2000). 
sentido da vida, para a perda do lugar do conselho. $O$ transtorno do ato de recordar repercute em todas as dimensões daquilo que constitui a organização de um referencial identitário de si e do mundo, e numa desorientação histórica, dado o eclipsamento do sentido da vida. O que Benjamin parece estar problematizando é a etiologia do fenômeno da alienação. A alienação é um conceito que também só pode ser compreendido levando-se em consideração o estado de coisas no interior do hífen. A alienação é uma situação de vida na qual, utilizando o modelo de Benjamin, o anjo da História é incapaz de escutar a demanda das ruínas e dos mortos, ou em que o anjo torto de Carlos Drummond de Andrade é incapaz de emergir da sombra e suscitar uma demanda. Em ambos os casos, na situação alienada, a vida se transforma em mero viver, e a febre em angústia.

Para Benjamin, não é a memória diretamente a operadora da narrativa. A memória só se transforma em narrativa graças à presença da morte:

Morrer, outrora um processo público e altamente exemplar (pense-se nas imagens da Idade Média, nas quais o leito de morte se metamorfoseava num trono, de encontro ao qual, através das portas escancaradas da casa mortuária, o povo ia se apinhando) - morrer, durante a Era Moderna, é cada vez mais repelido do mundo perceptível dos vivos. Antigamente, não havia uma casa, quase nem um quarto, em que alguém já não tivesse morrido... Em espaços que ficaram purificados da morte, os cidadãos hoje são habitantes enxutos de eternidade e, quando seu fim se aproxima, eles são dispostos pelos herdeiros em sanatórios ou hospitais. No entanto, não é só o saber ou a sabedoria do homem, mas acima de tudo sua vida vivida - a matéria de onde surgem as histórias - que assume forma transmissível primeiro naquele que morre. Da mesma maneira como no íntimo do homem entra em movimento, com o correr da vida, uma sequência de imagens - que consiste nos pontos de vista da própria pessoa, entre os quais sem se aperceber, ele encontra a si mesmo -, aos seus gestos e olhares incorpora-se de repente o inesquecível e transmite, a tudo que lhe disse respeito, a autoridade de que até o mais miserável pé-dechinelo dispõe diante dos vivos, na hora de morrer. Esta autoridade está na origem da narrativa. (p. 64)

A sombra que cai sobre o ego e que transtorna o luto, dando origem à melancolia, para Freud nada mais é do que a impossibilidade de lidar com a morte. Benjamin também relaciona o silêncio da narrativa com uma dificuldade de lidar com a morte. Se fizemos questão de trazer toda essa extensa citação, é para mostrar como pode ser rico relacionar História e Psicologia. Aqui não há redução nenhuma. Ao contrário, aqui a História pode ser compreendida como a parteira da experiência pessoal, que só emerge, graças à compreensão de Benjamin, quando dotada de uma autoridade que legitimamente pode estar ao alcance de qualquer 
homem, desde que se saiba mortal diante de uma vida humana que permanece. A narrativa, isto é, a experiência é o que um homem deixa de herança para os seus.

O que nos parece mais insólito nesse texto é o lugar que Benjamin dá à morte na incrível dialética que ele suscita para entender o fenômeno da experiência. Não se trata apenas de que o homem tem que se saber mortal. Trata-se de que dentro do hífen, no interior da memória, a morte tem que ter o seu lugar:é ela a promotora da dinamização da memória. Na cidade eterna de Freud, a morte tem que estar presente para que, da reunião de todas as edificações, um sentido possa emergir. O que o texto de Benjamin nos leva a conjecturar é que o hífen é tão humano quanto o homem, que a memória pessoal e a memória coletiva dos homens são feitas da mesma matéria que cada homem, ela também é mortal, ou melhor, o mortal habita no interior da memória, da mesma maneira como a morte limita cada homem. O hífen que a Psicanálise nos ajuda a pôr de manifesto não é nada mais nem nada menos do que o extrato a partir do qual o homem se manifesta como homem. Alocar a morte na memória é alocar a essência do homem na memória. Por isso, o estudo da Psicologia Social pode permitir a emergência de algo assim como uma antropologia da condição humana em cada situação histórica.

\section{On the field of Social Psychology}

Abstract: The field of Social Psychology is presented as a fertile territory, in contemporary times, to be constituted as a laboratory for the production in Human Sciences as, in the $20^{\text {th }}$. Century, the social took increasingly a path towards the psychological. In this field, our struggle is around the way we understand the hyphen that is pressuposed in the psycho-social integration. The author proposes that, between the psychological and the social, the hyphen dominates, as it is the proper relational essence that is inherent to each of these elements. She suggests that the model proposed by Freud to understand man and his circumstances imbricates in an undissociable way the psychological and the social, onthogenesis and phylogenesis, with a potency that had an impact on the whole field of Human Sciences.Psychoanalysis is an hermeneutic instrument to collaborate in the elucidation of social phenomena. The author uses images constructed by Freud and Walter Benjamin and poems of Carlos Drummond de Andrade to strenghten the understanding of the psycho-social hyphen both in its multidimensional action and organization.

Keywords: Social Psychology. Psychoanalysis. Memory. Raparation. 


\section{Sur le champ de la Psychologie Sociale}

Résumé: Le champ de la Psychologie Sociale est présenté comme un territoire fertile dans la contemporanéité, afin de se constituer comme un laboratoire de production dans les Sciences Humaines, puisque au XXème siècle, le social prenait de plus en plus une dimension psychologique. Dans ce domaine, notre collision se manifeste dans la manière dont nous interprétons le trait d'union impliqué dans l'intégration psychosocial. L'auteure propose qu'entre le psychologique et le social, c'est le trait d'union qui domine. Ce dernier est la propre essence relationnelle inhérente à chacun des éléments. Elle suggère que le modèle permettant de comprendre l'être humain et son environnement proposé par Freud, imbrique de façon indissociable le psychologique et le social, l'ontogénèse et la filogénèse, avec une potence qui a eu un impact sur tous les Sciences Humaines. La Psychanalyse est un instrument herméneutique pour contribuer à l'explication des phénomènes sociaux. L'auteure utilise des images construites par Freud et Walter Benjamin et des poèmes de Carlos Drummond de Andrade afin de renforcer un entendement du trait d'union psychosocial, tant dans son action multidimensionnelle que dans son organisation.

Mots-clés: Psychologie Sociale.Psychanalyse. Mémoire. Réparation.

\section{Sobre el campo de la Psicología Social}

Resumen: El campo de la Psicología Social es presentado como territorio fértil en la contemporaneidad, para constituirse como un laboratorio para la producción en Ciencias Humanas, ya que en el siglo XX cada vez más el social fue en dirección hacia el psicológico. En este campo, nuestro embate se da en la manera como entendemos el guión presupuesto en la integración psicosocial. La autora propone que entre el psicológico y el social el guión domina, pues él es la propia esencia relacional que es inherente a cada uno de los elementos. Sugiere que el modelo para entender el hombre y sus circunstancias propuesto por Freud imbrica de forma indisociable el psicológico y el social, la ontogénesis y la filogénesis, con una potencia que tuvo impacto sobre todo el campo de las Ciencias Humanas. El Psicoanálisis es un instrumento hermenéutico para colaborar en la elucidación de los fenómenos sociales. La autora utiliza imágenes construidas por Freud y Walter Benjamin y poemas de Carlos Drummond de Andrade para fortalecer el entendimiento del guión psicosocial tanto en su acción multidimensional como en su organización.

Palabras clave: Psicología Social.Psicoanálisis. Memoria. Reparación. 


\section{Referências}

Abraham, N., \& Torok, M. (1994). The shell and the kernel: Renewals of psychoanalysis (Vol. 1). Chicago:The University of Chicago Press.

Andrade, C.D. (1987). Antologia poética. Rio de Janeiro: Record.

Benjamin, W. (1971). Tesis de la filosofia de la historia. In W. Benjamin, Angelus Novus (pp.77-82). Barcelona:Edhasa.(Trabalho original publicado em 1940)

Benjamin, W. (1980). O narrador. Observações acerca da obra de Nicolau Leskow. In Textos escolhidos: Walter Benjamin, Max Horkheimer, Theodor W. Adorno, Jürgen Habermas (Coleção Os Pensadores). São Paulo: Abril Cultural. (TrabaIho original publicado em 1969)

Bloom, H. (2002). Angústia da influência. Uma teoria da poesia. Rio de Janeiro: Imago.

Ferenczi, S. (1981). Reflexiones sobre el traumatismo. In S. Ferenczi, Obras completas (Vol. 4). Madrid: Espasa Calpe. (Trabalho original publicado em 1933)

Freud, S. (1976). Estudos sobre a histeria. In S. Freud, Edição standard das obras psicológicas completas de S. Freud (J. Salomão, trad., Vol. 1). Rio de Janeiro: Imago. (Trabalho original publicado em 1895)

Freud, S. (1976). A interpretação dos sonhos. In S. Freud, Edição standard das obras psicológicas completas de S. Freud (J. Salomão, trad., Vol. 5, cap. 7: A regressão). Rio de Janeiro: Imago. (Trabalho original publicado em 1900)

Freud, S. (1976).Totem e tabu. In S. Freud, Edição standard das obras psicológicas completas de S. Freud (J. Salomão, trad., Vol. 13). Rio de Janeiro: Imago. (Trabalho original publicado em 1913)

Freud, S. (1976). Conferências introdutórias sobre psicanálise. Conferência XXI: O desenvolvimento da libido e as organizações sexuais. In S. Freud, Edição standard das obras psicológicas completas de S. Freud (J. Salomão, trad., Vol. 16, p. 376). Rio de Janeiro: Imago. (Trabalho original publicado em 19161917)

Freud, S. (1976). Luto e melancolia. In S. Freud, Edição standard das obras psicológicas completas de S. Freud (J. Salomão, trad., Vol. 14, p. 281). Rio de Janeiro: Imago. (Trabalho original publicado em 1917)

Freud, S. (1976). Além do princípio de prazer, psicologia de grupo e outros trabaIhos: Psicologia de grupo e a análise do ego. In S. Freud, Edição standard das 
obras psicológicas completas de S. Freud (J. Salomão, trad., Vol. 18). Rio de Janeiro: Imago. (Trabalho original publicado em 1920-1921)

Freud, S. (1976). O futuro de uma ilusão, o mal-estar na civilização e outros trabaIhos. In S.Freud, Edição standard das obras psicológicas completas de S. Freud (J.Salomão, trad., Vol. 21, pp. 87-88, 105). Rio de Janeiro: Imago. (Trabalho original publicado em 1930)

Freud, S. (1976). Novas conferências introdutórias sobre Psicanálise e outros trabalhos. Conferência XXXV. A questão de uma Weltanschauung. In S. Freud, Edição standard das obras psicológicas completas de S. Freud (J. Salomão, trad., Vol. 22, p. 220). Rio de Janeiro: Imago. (Trabalho original publicado em 1933)

Freud, S.,\& Fliess,W. (1986). A correspondência completa de S.Freud para W. Fliess. Rio de Janeiro: Imago. (Trabalho original publicado em 1887-1902)

Marcuse, H. (1979). A ideologia da sociedade industrial. Rio de Janeiro:Zahar. (Trabalho original publicado em 1964)

Patto, M. H. S., \& Frayze-Pereira, J. A. (2007). Pensamento cruel - humanidades e Ciências Humanas: há lugar para a Psicologia? São Paulo: Casa do Psicólogo.

Robben, A., \& Suarez-Orosco, M. (Orgs.). (2000). Cultures under siege: Collective violence and trauma. Society for Psychological Anthropology: Cambridge University Press. 
Belinda Mandelbaum, Professora Associada do Departamento de Psicologia Social e do Trabalho do Instituto de Psicologia da Universidade de São Paulo. Endereço para correspondência: Av. Prof. Mello Moraes, 1721, Bloco A, Cidade Universitária, São Paulo, SP, Brasil.CEP:01229-010. Endereço eletrônico: belmande@usp.br

Recebido:17/03/2011

Aceito: 01/06/2011 